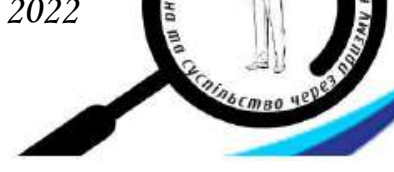

УДК $351: 61(477)$

https://doi.org/10.52058/2786-5274-2022-1(3)-21-34

Гавриченко Дмитро Георгійович кандидат медичних наук, завідувач кафедри анестезіології, інтенсивної терапії та медицини болю, Одеський медичний інститут Міжнародного гуманітарного університету, Фонтанська дорога, буд.23a, м.Одеса, 65000, тел.: (063) 519-13-41, https://orcid.org/0000-0003-1595-4467.

\title{
ДЕРЖАВНЕ РЕГУЛЮВАННЯ ТРАСФОРМАЦІЙ У СФЕРІ ОХОРОНИ ЗДОРОВ'Я УКРАЇНИ
}

Анотація. В умовах направленості урядової політики на підвищення рівня довіри до державної влади, впровадження євроінтеграційного курсу та глобалізаційних обов'язків країни, необхідним завданням $\epsilon$ визначення потенційних шляхів та напрямів розв'язання проблем в сфері охорони здоров'я, впровадження нових фінансових механізмів, нормативних та інноваційних трансформацій. У статті розглянуто особливості державного регулювання сфери охорони здоров'я 32015 року, визначено напрямки розвитку державних механізмів щодо впровадження подальших трансформацій та реформування цієї сфери. Метою статті $\epsilon$ аналіз нормативно-правового механізму впровадження трансформацій у систему охорони здоров'я для забезпечення ефективного реформування сфери охорони здоров'я та виявлення можливостей впровадження електронних послуг в цій сфері, що надасть змогу забезпечити якість та безпеку їх надання суспільству. Визначено головні цілі уряду спрямованні на сферу охорони здоров'я України: забезпечення рівного і справедливого доступу до медичних послуг, забезпечення мікроекономічної ефективності, макроекономічний контроль за видатками в сфері охорони здоров'я. Аналіз стратегічного базису нормативно-правового механізму впровадження трансформацій у систему охорони здоров'я надав змогу обгрунтувати принципи розвитку системи охорони здоров'я подальші кроки щодо їх реалізації. На основі дослідження проблем організаційного, нормативно-правового, соціально-економічного, технологічного характеру щодо впровадження електронних довірчих послуг у сфері охорони здоров'я, визначено, що запровадження інформаційно-телекомунікаційних систем підтримки автоматизації адміністративних процесів та прийняття управлінських рішень є основними завданнями державного регулювання у сфері охорони здоров'я. Доведено, що вирішення проблем у реформуванні та трансформації сфери охорони здоров'я потребує державної підтримки, на рівнях центральних органів виконавчої влади та суб'єктів законодавчої ініціативи прийняття управлінських рішень, розробки нових нормативно- 
правових актів, налагодження взаємодії між громадськістю, бізнесом, державою, міжнародної співпраці 3 інститутами Свропейського Союзу, що сприятиме покращенню глобальних результатів системи охорони здоров'я в Україні.

Ключові слова: державне регулювання, сфера охорони здоров'я, електронні довірчі послуги, трансформація

Havrychenko Dmytro Heorhijovych PhD in Medical Sciences, Head of the Department of Anesthesiology, Intensive Care and Pain Medicine, Odesa Medical Institute of the International Humanitarian University, Fontanskaya road, 23a, Odessa, 65000, tel.: (063) 519-13-41, https://orcid.org/0000-0003-1595-4467.

\section{PUBLIC REGULATION OF TRANSFORMATIONS IN THE FIELD OF UKRAINIAN PUBLIC HEALTH}

Abstract. Under circumstances of public policy's orientation on increasing confidence in public authorities, implementation of European integration's course as well as globalization responsibilities of the country, the necessary tasks are to identify potential ways and directions of solving problems in the field of public health, to introduce new financial mechanisms, normative and innovative transformations. The article considers features of public regulation in the field of public health since 2015, identifies prospects for public mechanisms' development of further transformations implementation and reforming of this area. The purpose of the article is to analyze the normatively-legal mechanism of implementing transformations in public health system to ensure its effective reforming and to identify opportunities for the introduction of electronic services in this area, which will ensure quality and safety of its provision to society. The main governmental goals in the field of Ukrainian public health are defined: ensuring equal and fair access to medical services, ensuring microeconomic efficiency, macroeconomic control over health care expenditures. Analysis of strategic basis for normativelylegal mechanism of transformations implementation in public health system provided an opportunity to substantiate the principles of this system's development as well as further steps for its implementation. Based on the study of organizational, normatively-legal, socio-economic, technological issues related to the introduction of electronic trust services in public health, it is defined that implementation of information and telecommunication support systems for automation of administrative processes and making management decisions are the main tasks of public regulation of the health care. It is proved that solving problems in reforming and transforming of public health requires state support at the levels of central executive bodies and subjects of legislative initiative in making managerial decisions, developing new regulations, establishing interaction between public, business, state, international cooperation with the institutions of the European Union, which will assist in 
improving the global outcomes of the Ukrainian public health system.

Keywords: public regulation, public health, electronic trust services, transformation

Постановка проблеми. Система охорони здоров'я в Україні була сформована на моделі з жорсткими процедурами державного фінансування та управління. Це стало причиною високого рівня корупції, неефективності роботи системи, відсутності сучасних світових тенденцій, ігнорування потреб населення, відсутності модернізації в національній системі охорони здоров'я. В умовах впровадження євроінтеграційного курсу та глобалізаційних обов'язків країни, стало необхідним визначення потенційних шляхів та напрямів розв'язання проблем в сфері охорони здоров'я, для формування нової державної політики у галузі, включаючи впровадження нових фінансових механізмів, нормативних та інноваційних трансформацій.

Сучасність вимагає від кожної країни високого рівня довіри до державної влади. Однак, для забезпечення такої стовідсоткової довіри необхідно забезпечити прозорість діяльності органів державної влади, що надасть змогу залучити суспільство. Таким інструментом можуть стати електронні послуги, які дозволять встановити (підвищити) відповідальність влади перед суспільством. Якість надання електронних послуг $є$ показником ставлення державної влади до осіб, ступеня поваги до їх прав і свобод. Національна політика розвитку інформаційного суспільства в Україні грунтується на засадах: створення загальнодоступних електронних інформаційних ресурсів; збільшення кількості та різноманітності електронних послуг, широкого впровадження інформаційно-комунікаційних технологій в освіту, науку, охорону здоров'я, культуру, охорону навколишнього середовища; формування необхідних для цього законодавчих і сприятливих економічних умов. Обмін, поширення та використання інформації та знань підвищення якості даних $€$ результатом зміцнення інформаційних технологій, що сприяє підвищенню підзвітності, прозорості, економічної ефективності надання послуг.

Аналіз останніх досліджень і публікацій. У процесі дослідження широко використовувалися результати вчених Marc Suhrcke [1], Martin McKee [1], Lorenzo Rocco [1], Братішко Ю. [2], Бурик 3.[3], Дегтяр О. [2], Деренська Я. [2], Козирєва О. [2], Куцак Ю. [4]. Лехан В. [5], Москаленко В. [6], Мохова Ю. [2], Орлова Н. [2-3,7], Попченко Т. [8], Ситаш Т.Д. [9], Слабкий Г. [5], Шевченко М.[5], які займалися i продовжують дослідження питаннь реформування системи охорони здоров'я, фінансуванням охорони здоров'я та вивчали досвід зарубіжних країн щодо впровадження сучасних інформаційних технологій у визначеній сфері. Проте, комплексного наукового дослідження щодо сучасних трансформацій в сфері охорони здоров'я не здійснювалося, тому варто було б визначити нові ефективні державні важелі розвитку охорони здоров’я в Україні. 
Наукові дослідження німецького філософа А. Шопенгауер свідчать, що здоров'я перевищує усі інші блага життя, а здоровий жебрак - щасливіший, ніж хворий король. Здоров'я людини $є$ не лише однією з найважливіших життєвих цінностей, основою життя людини та способом її існування, але й одним із визначальних чинників розвитку економіки країни, показником iї благополуччя, індикатором результативності та ефективності соціальних реформ, особливо в період економічної кризи. Саме ступінь соціальної орієнтованості держави на вдосконалення діяльності сфери охорони здоров'я $\epsilon$ одним із показників іiї цивілізованості й конкурентоспроможності [1].

Експерти Всесвітньої Організації Охорони Здоров’я (ВОО3) визначають чинником підвищення національного доходу, довготривалого стійкого економічного зростання саме здоров'я населення, яке сприяє зниженню рівня бідності, безперервному економічному зростанню, впливає на соціальне благополуччя [5].

Статтею 49 Конституції України визначено, що кожен громадянин має право на медичну допомогу, охорону здоров'я, медичне страхування. Відповідно до медико-санітарних, соціально-економічних, оздоровчопрофілактичних програм охорона здоров'я забезпечується державним фінансуванням. Уряд формує умови для доступного для всіх та ефективного медичного обслуговування. Діюча мережа таких закладів не може бути скорочена. Держава забезпечує санітарно-епідемічне благополуччя, дбає про розвиток спорту, фізичної культури та сприяє розвиткові лікувальних закладів усіх форм власності [10].

Метою статті $є$ аналіз нормативно-правового механізму впровадження трансформацій у систему охорони здоров'я для забезпечення ефективного реформування сфери охорони здоров'я та виявлення можливостей впровадження електронних послуг в цій сфері, що надасть змогу забезпечити якість та безпеку їх надання для суспільства.

Виклад основного матеріалу. Складовою Національного плану дій 3 реформування системи охорони здоров'я в Україні $\epsilon$ Національна стратегія реформування системи охорони здоров'я в Україні на період 2015-2020 роки (Стратегія), затверджена програмою діяльності Кабінету Міністрів України (постанова Верховної ради України від 11 грудня 2014 року №26-VIII) та Указом Президента України 722/2019 від 30.09.2019 «Про Стратегію сталого розвитку «Україна - 2030». Стратегія представляє собою рамковий документ, який формує бачення, контекст, пріоритети, задачі, принципи, подальші кроки реформування вітчизняної системи охорони здоров'я. Стратегія є основою для прийняття рішень та розробки політики в галузі охорони здоров'я щодо бюджетних ресурсів та фінансування у сфері охорони здоров'я. Наразі, триває розробка Стратегії розвитку системи охорони здоров'я до 2030 року. 


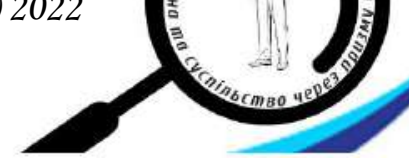

За Національною стратегією реформування системи охорони здоров'я в Україні на період 2015-2020 рр. ключовими принципами системи охорони здоров'я є:

1. Гарантований доступний пакет послуг для кожного громадянина. Принцип повинен бути застосований незалежно від віку, статі, політичних та релігійних переконань, сексуальної орієнтації, цивільного або сімейного стану. Він повинен базуватися на повазі до прав людини та бути застосований до кожного та всіх в цілому. Особливу увагу уряд має приділяти вразливим соціальним групам.

2. Дотримання національних стандартів професіоналізму та якості. Принцип спрямований на надання якісної, ефективної, безпечної медичної допомоги, спрямованої на підтримку, задоволення потреб, розвиток персоналу, освіту пацієнта, удосконалення управління галуззю.

3. Взаємоповага медичних працівників та пацієнтів. Першим та головним принципом у роботі з пацієнтами мають бути гідність, повага, турбота та співчуття. Коли пацієнти будуть відчувати себе партнером, а медичні працівники матимуть підтримку, відповідні повноваження, відчуватимуть свою цінність, будуть покращуватися їх досвід, безпека, результати для здоров'я.

4. Співпраця різних служб, секторів економіки, організацій в інтересах населення, громад, пацієнтів (міжсекторальна взаємодія). Для підвищення рівня добробуту та здоров'я система охорони здоров'я повинна взаємодіяти 3 органами державного сектору, іншими службами, широким колом благодійних організацій, громадських об'єднань, юридичних осіб приватної форми власності.

5. Найбільш справедливе, ефективне, стійке використання обмежених ресурсів та співвідношення ціна-якість. Державні кошти на охорону здоров’я повинні бути направлені виключно на благо громадян. Головною метою уряду має бути - кожна витрачена гривня платником податків має приносити для здоров’я людей більше результату.

6. Підзвітність пацієнтам та громадам. Система підзвітності та відповідальності за прийняття рішень повинна бути зрозумілою та прозорою для пацієнтів, персоналу, громадськості. Для реалізації поставленої мети уряд має гарантувати постійну можливість доступу до основних показників здоров'я та інформації, а органи місцевої та центральної влади систематично звітувати перед радами (представниками), громадою за результати діяльності в сфері охорони здоров'я.

Система охорони здоров'я в Україні - це комплексна галузь, яка повинна грунтуватися на принципах ефективної взаємодії багатьох центральних органів влади на рівні Міністерств охорони здоров'я, фінансів, економіки, праці та соціальної політики, освіти і науки, з питань надзвичайних ситуацій та інших міністерств та відомств [4]. Кардинальні зміни у соціально-економічній сфері, незадовільний стан здоров'я населення, недоліки сучасної системи охорони 
здоров'я, критична демографічна ситуація, незадовільна екологічна ситуація вимагають поліпшення та удосконалення організації діяльності галузі, нагального вирішення іiі актуальних проблем.

Майбутня система охорони здоров'я має базуватися на трьох фундаментальних принципах, які мають бути відображеними на кожному наступному етапі реформи та застосовуватися в усіх секторах охорони здоров'я, а саме:

1. Система охорони здоров'я має бути орієнтована на людей, дослухатися до потреб людей (працівників, пацієнтів), формувати атмосферу, яка постійно оцінюється та є підставою для покращення роботи. Нові моделі фінансування послуг системи охорони здоров'я мають зменшувати фінансові ризики, бути ефективними, відкривати доступ до відповідних послуг;

2. Головним завданням системи охорони здоров'я в умовах трансформацій $\epsilon$ безпека та якість послуг, їх здатність адаптуватися до постійно змінюваних викликів;

3. Система охорони здоров’я складається з соціальних інституцій, робота яких залежить від стосунків між різними учасниками системи (дослідників, управлінців, покупців, постачальників, тощо). Лише шляхом формування взаємоповаги, діалогу, довіри між цими суб'єктами може бути досягнуто процвітання, а від якості таких стосунків залежатиме ефективність роботи.

Розробка державної програми медичних гарантій на 2020 рік стала одним iз стратегічних направлень уряду. Вперше вона була ухвалена в 2020 році та включає за принципом «гроші йдуть за пацієнтом» всі рівні надання медичних послуг, які оплачуватиме Національна служба здоров'я у 2020 році. Зміни у медичній освіті $є$ невід'ємною складовою трансформації системи охорони здоров'я в цілому. Система повинна базуватися на розумінні відповідальності за загальне благополуччя населення, здоров’я, усі аспекти життя.

В сучасній вітчизняній системі охорони здоров'я наявні ряд загроз національній безпеці, серед яких можна виділити: нераціональне та недостатнє використання джерел фінансування, а також недосконалість господарського статусу, організаційної структури закладів охорони здоров'я, недосконалість бюджетних механізмів фінансування та управління коштами. Державні кошти $\epsilon$ ключовим джерелами фінансування охорони здоров'я України. Тому потребують детального дослідження шляхи підвищення ефективності фінансового забезпечення охорони здоров'я в Україні.

За п'ять років 3 початку реформування системи охорони здоров'я відбулися значні трансформації у механізмах фінансування цієї сфери. Побудова нової національної системи охорони здоров'я передбачає багатоканальність фінансування відповідно до розпорядження Кабінету Міністрів України «Про схвалення Концепції побудови нової національної системи охорони здоров'я України» від 14.07.2014 р. [11]. Концепція розвитку системи фінансового забезпечення у сфері охорони здоров'я, затверджена 
розпорядженням Кабінету Міністрів України від 18.09.2013 р. № 776-р. [12], розроблена з урахуванням напрямів діяльності Світового банку, Свропейської комісії, ВОО3, інших міжнародних організацій, міжнародного досвіду фінансового забезпечення галузі охорони здоров'я.

Системні зміни в сфері охорони здоров'я України включають зміну принципів фінансування галузі. Розпорядженням Кабінету Міністрів України від 30.11.2016 № 1013-р. затверджено Концепцію реформи фінансування системи охорони здоров'я [13].

У грудні 2017 року прийнято Закон України «Про внесення змін до Бюджетного кодексу України», «Про державні фінансові гарантії медичного обслуговування населення», які започаткували реформу охорони здоров'я в Україні [14-15]. Вирішення проблем охорони здоров'я (катастрофічні витрати домогосподарств на охорону здоров'я, неефективне витрачання бюджетних коштів, низька ефективність та якість надання медичних послуг) є головною метою реформи.

Протягом 2017 року у всіх регіонах України проведено консультації щодо впровадження реформи за участю міжнародних, громадських організацій та Міністерства охорони здоров'я. 19 жовтня 2017 року прийнято Закон України «Про державні фінансові гарантії медичного обслуговування населення», внесені необхідні зміни до Державного бюджету. 14 листопада 2017 року ухвалено Закон «Про підвищення доступності та якості медичного обслуговування у сільській місцевості» $[14,16]$.

В квітні 2018 року стартувала національна кампанія з вибору педіатрів, терапевтів, сімейних лікарів без прив'язки до місця реєстрації пацієнтів. Більше 20 млн. українців за сім місяців підписали декларації про вибір лікарів. Кожен другий українець вже має лікаря, до якого може звернутися з будьякими проблемами зі здоров'ям, якому довіряє, в якого можна дізнатися, як не хворіти та вести здоровий спосіб життя.

3 другої половини 2019 року розпочалась програма «Безкоштовна діагностика» - наступний етап після реформи первинної ланки. Це 80\% потреби пацієнта 3 діагностики у педіатра, терапевта, сімейного лікаря. Затребуваними $є$ послуги вузькопрофільних спеціалістів, безоплатні аналізи та дослідження. Пацієнти можуть за направленням лікаря проходити наступні обстеження: ультразвукову діагностику, рентген, ехокардіографія серця, мамографія, інші обстеження - у будь-якому медичному закладі безоплатно за договорам 3 Національною службою здоров'я України. Таким чином, поліклініки, які є установами амбулаторної спеціалізованої допомоги, будуть переходити на нову модель фінансування [17].

Пріоритетним завданням системи охорони здоров'я будь-якого уряду $є$ забезпечення належного рівня здоров'я населення, що визначається стратегічними документами національного, європейського та міжнародного рівнів [9]. В сфері охороні здоров'я основними цілями уряду є забезпечення 
мікроекономічної ефективності, забезпечення справедливого та рівного доступу до медичних послуг, макроекономічний контроль за видатками в сфері охорони здоров'я (табл. 1).

Таблиия 1

Головні цілі уряду спрямованні на сферу охорони здоров'я України

\begin{tabular}{|c|c|}
\hline Ціль & Результат \\
\hline $\begin{array}{l}\text { Забезпечення } \\
\text { рівного i } \\
\text { справедливого } \\
\text { доступу до } \\
\text { медичних послуг }\end{array}$ & $\begin{array}{l}\text { Громадяни повинні мати доступ до певного } \\
\text { гарантованого мінімального рівня послуг, в межах } \\
\text { якого медична допомога повинна надаватись в } \\
\text { залежності від потреби хворого в ній, а не в } \\
\text { залежності від здатності хворого за неї платити }\end{array}$ \\
\hline $\begin{array}{l}\text { Забезпечення } \\
\text { мікроекономічної } \\
\text { ефективності }\end{array}$ & $\begin{array}{l}\text { Якість допомоги і ступінь задоволення пацієнтів } \\
\text { повинні бути максимально можливими при } \\
\text { мінімально можливих затратах ресурсів }\end{array}$ \\
\hline $\begin{array}{lr}\text { Макроекономічний } \\
\text { контроль } \\
\text { видатками в сфері } \\
\text { охорони здоров'я }\end{array}$ & $\begin{array}{l}\text { Сектор охорони здоров'я повинен поглинати } \\
\text { «розумну» частку валового національного } \\
\text { продукту (зростання рівня видатків на охорону } \\
\text { здоров'я) }\end{array}$ \\
\hline
\end{tabular}

Україна гостро потребує трансформаційних механізмів в системі охорони здоров’я та переорієнтації підходів до управління і фінансування галузі в цілях поліпшення доступності і якості медичного обслуговування в державі. Стан здоров'я населення, якість медичного обслуговування залежать від ефективного використання та забезпеченості медичної галузі трудовими, матеріально-технічними, фінансовими ресурсами. Таким чином, сучасна система охорони здоров'я вимагає формування такої державної політики, яка дозволить охопити основними видами профілактики, допомоги, лікування i реабілітації все населення, забезпечити надання медичних послуг достатніми фінансовими ресурсами, підвищити ефективність та зменшити фінансові ризики, пов’язані з наданням допомоги.

Доступність медичної допомоги це основна мета системи охорони здоров'я населення, а іiі передумови полягають у збалансованості необхідних обсягів медичної допомоги з можливостями та ресурсами держави.

Якість медичної допомоги в свою чергу, відзначається сукупністю характеристик, що підтверджують відповідність наданої медичної допомоги наявним потребам пацієнта, його очікуванням, сучасному рівню розвитку медичної науки і технології. Основними характеристиками якості медичної допомоги $є$ адекватність, доступність, наступність і безперервність, безпека, результативність ефективність, дієвість, своєчасність, задоволення очікувань і потреб, стабільність процесу й результату, постійне вдосконалення та поліпшення. 


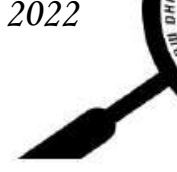

Протягом років незалежності України різними урядами країни та органами місцевого самоврядування здійснювались заходи щодо створення інформаційних систем місцевого та загальнодержавного масштабу для надання в електронному вигляді адміністративних послуг [18]. Надання таких послуг передбачає онлайн взаємодію через певні інтерфейси інформаційної системи 3 використанням механізмів електронної автентифікації та ідентифікації між органом, що надає послугу, та громадянином на принципах гарантій впевненості та безпеки.

Наслідки та причини відсутності в Україні сталої інфраструктури електронних довірчих послуг можна систематизувати за напрямами: технологічний, соціально-економічний, нормативно-правовий та організаційний, які наведено в табл.2.

Наведені наслідки та причини відсутності в Україні умов побудови довірчої інфраструктури електронної ідентифікації свідчить про те, що в умовах належного технічного та нормативного регулювання, в умовах узгодження заходів із кібернетичної безпеки загальною концепцією розбудови інформаційного суспільства, соціально-економічними програмами, гарантованого ресурсного забезпечення, націленості на перспективу інтеграції iз єдиним цифровим ринком Європи вирішення наявних проблеми $\epsilon$ неефективним.

Таблиия 2

\section{Проблеми розвитку електронних довірчих послуг в Україні}

\begin{tabular}{|c|c|}
\hline $\begin{array}{c}\text { Направленість } \\
\text { проблеми } \\
\text { розвитку } \\
\end{array}$ & Характеристика \\
\hline & 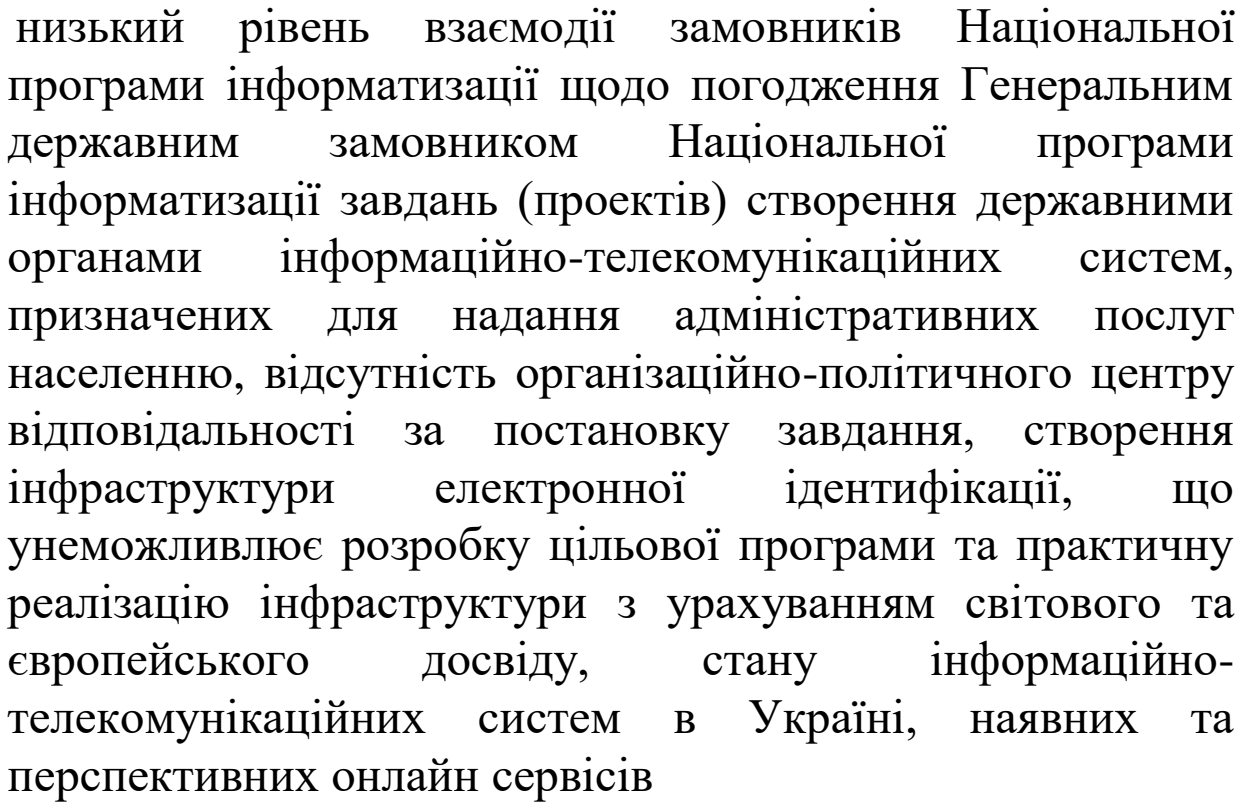 \\
\hline
\end{tabular}




\begin{tabular}{|c|c|}
\hline & $\begin{array}{l}\text { відсутність чіткої нормативно-правової бази, що } \\
\text { визначала б повноваження та компетенції державних } \\
\text { органів щодо нормативного та технічного регулювання } \\
\text { сфери електронної ідентифікації; } \\
\text { відсутність в нормативному полі України поняття } \\
\text { електронного паспорта громадянина України як } \\
\text { документа, що посвідчує особу; } \\
\text { недостатнє покриття національними стандартами та } \\
\text { технічними специфікаціями сфери електронної ідентифікації }\end{array}$ \\
\hline $\begin{array}{l}\text { екоІ } \\
\text { кон }\end{array}$ & 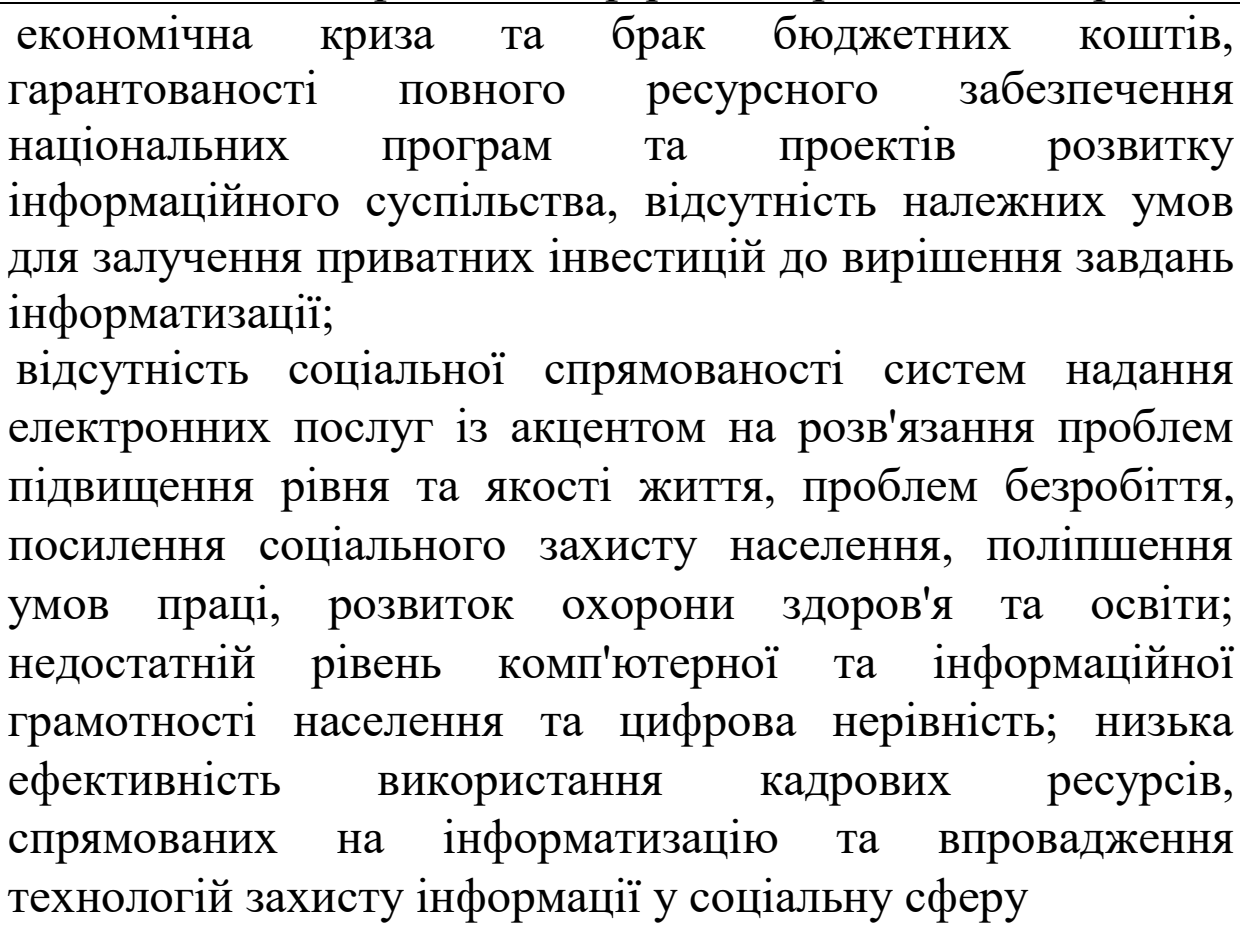 \\
\hline & $\begin{array}{l}\text { зростання кіберзлочинності в умовах збільшення } \\
\text { кількості інформаційних систем, що здійснюють } \\
\text { оброблення даних про особистість у масштабах; } \\
\text { відсутність захищеного обміну ідентифікаційними } \\
\text { даними фізичних та юридичних осіб, які обробляються в } \\
\text { інформаційних системах органів державної влади та } \\
\text { приватного сектору }\end{array}$ \\
\hline
\end{tabular}

Вирішення проблеми потребує координації діяльності органів місцевого самоврядування, місцевих та центральних органів виконавчої влади, державної підтримки, на рівнях центральних органів виконавчої влади та суб'єктів законодавчої ініціативи прийняття управлінських рішень, розробки низки нормативно-правових актів, узгодження дій суб'єктів відповідальних за розробку функціональних та архітектурних рішень, участі у його галузевих програмних проектах, налагодження взаємодії між громадськістю, бізнесом, державою, міжнародної співпраці з інститутами Свропейського Союзу. 
Підтримка та розвиток безпечних, прозорих, доступних, найменш затратних, не корупційних, зручних та швидких електронних послуг (електронного рецепту) дасть змогу підвищити конкурентоспроможність та мобільність публічних послуг, покращити якість їх надання юридичним та фізичним особам, зменшити корупційні ризики. Нові IT-послуги на рівні Міністерства охорони здоров'я допоможуть зміцнити потенціал у сфері моніторингу, реалізації, планування програм у сфері охорони здоров’я.

Висновки. На основі дослідження сучасних тенденцій розвитку системи охорони здоров'я, електронних довірчих послуг, принципів, стратегії реформування системи охорони здоров'я в Україні виділено основні напрямки розвитку механізму державного регулювання сфери охорони здоров'я. Проаналізована нормативно-законодавча база трансформацій у сфері охорони здоров’я надала змогу виявити проблеми розвитку та головні цілі уряду, які спрямованні на трансформації зазначеної системи.

Також, обгрунтовано перспективи розвитку електронних довірчих послуг в системі охорони здоров'я в соціальному, технологічному, законодавчому аспектах, що надасть змогу підвищити показники здоров'я населення в Україні (тривалості життя, зниження захворюваності, смертності), збільшити фінансову захищеність громадян, забезпечити готовність та здатність системи охорони здоров'я ефективно реагувати на кризові ситуації.

Потребує подальших досліджень проблеми та механізми фінансування сфери охорони здоров'я, а також подальші можливості держави у наданні електронних послуг населенню.

\section{Jimepamypa:}

1. Marc Suhrcke, Martin McKee, Lorenzo Rocco. Health: a vital investment for economic development in eastern Europe and central Asia. The European Observatory on Health Systems and Policies, 2007, pp. 249.

2. Orlova N., Mokhova I., Kozyrieva O., Diegtiar O., Derenska Y., Bratishko Y Public Information Policy in Health Care Sector: Ukrainian Perspectives // International Business Information Management Conference, Seville, Spain 1-2 April, 2020 pp. 341-351.

3. Орлова Н.С., Бурик 3.М. Державна інформаційна політика в Україні в сфері охорони здоров'я // Експерт: парадигми юридичних наук і державного управління. 2021. №2. С. 233-242.

4. Куцак Ю. Г. Фінансування охорони здоров'я та медичне страхування в Україні.

http://www.rusnauka.com/Medecine

5. Лехан В.М., Слабкий Г.О., Шевченко М.В. Стратегія розвитку системи охорони здоров’я: український вимір // Україна. Здоров’я нації. 2010. №1. С.5-23

6. Москаленко В. Ф. Принципи організації оптимальної моделі системи охорони здоров’я: український контекст: монографія. Київ: «Книга плюс», 2008. 320 с.

7. Орлова Н. С. Механізми державного управління у реформуванні системи охорони здоров’я // Публічне адміністрування та національна безпека. 2019. №6.

https://doi.org/10.25313/2617-572X-2019-6-5377 
8. Попченко Т. П. Реформування сфери охорони здоров’я в Україні: організаційне, нормативно-правове та фінансово-еконјмічне забезпечення: аналітична доповідь. Київ: НІСД, 2012. С. 5

9. Ситаш Т.Д. Фінансування системи охорони здоров'я в Україні: тенденції та реформування // Механізм регулювання економіки. 2012. №1. С.164-169.

10. Конституція України. http://zakon2.rada.gov.ua/rada/show/254к/96-вр

11. Про схвалення Концепції побудови нової національної системи охорони здоров’я України: проект розпорядження Кабінету Міністрів України від 14.07.2014 р.

https://www.apteka.ua/article/295842

12. Про схвалення Концепції розвитку системи фінансового забезпечення у сфері охорони здоров’я: розпорядження Кабінету Міністрів України від 18.09.2013 р. №776-р.

https://www.kmu.gov.ua/npas/246773163

13. Про схвалення Концепції реформи фінансування системи охорони здоров'я: розпорядження Кабінету Міністрів України від 30 листопада 2016 р. №1013-р.

https://zakon.rada.gov.ua/laws/show/1013-2016-\%D1\%80

14. Про державні фінансові гарантії медичного обслуговування населення: Закон України від 19 жовтня 2017 року №2168-VIII.

https://zakon.rada.gov.ua/laws/show/2168-19

15. Про внесення змін до Бюджетного кодексу України: Закон України від 22 листопада 2018 року № 2621-VIII.

https://zakon.rada.gov.ua/laws/show/2621-19

16. Про підвищення доступності та якості медичного обслуговування у сільській місцевості: Закон України від 14 листопада 2017 року № 2206-VIII.

https://zakon.rada.gov.ua/laws/show/2206-19\#Text

17. Що змінилося за рік після прийняття закону про медичну реформу.

https://moz.gov.ua/article/reform-plan/scho-zminilosja-za-rik-pislja-prijnjattjazakonu-pro-medichnu-reformu--

18. Досвід країн Свропи у фінансуванні галузі охорони здоров'я, уроки для України. http://eeas.europa.eu/delegations/ukraine/documents/virtual_library/14_reviewbook_uk.pdf

\section{References:}

1. Suhrcke, M., McKee, M. Lorenzo Rocco, L. (2007). Health: a vital investment for economic development in eastern Europe and central Asia. The European Observatory on Health Systems and Policies [in English].

2. Orlova, N., Mokhova, I., Kozyrieva, O., Diegtiar, O., Derenska, Y. and Bratishko, Y. (2020). Public Information Policy in Health Care Sector: Ukrainian Perspectives. International Business Information Management Conference, Seville, Spain [in English].

3. Orlova, N.S. and Buryk, Z.M. (2021). Derzhavna informatsijna polityka v Ukraini v sferi okhorony zdorov'ia [Government information policy in Ukraine in the field of health care]. Ekspert: paradyhmy iurydychnykh nauk $i$ derzhavnoho upravlinnia - Expert: paradigms of legal sciences and public administration, 2, 233-242 [in Ukrainian].

4. Kutsak, Yu. H. Finansuvannia okhorony zdorov'ia ta medychne strakhuvannia v Ukraini [Health care financing and health insurance in Ukraine]. (n.d.). rusnauka.com. Retrieved from http://www.rusnauka.com/Medecine [in Ukrainian]. 
5. Lekhan, V.M., Slabkyj, H.O. and Shevchenko, M.V. (2010). Stratehiia rozvytku systemy okhorony zdorov'ia: ukrains'kyj vymir [Health care development strategy: the Ukrainian dimension]. Ukraina. Zdorov'ia natsii - Ukraine. The health of the nation, 1, 5-23 [in Ukrainian].

6. Moskalenko, V. F. (2008). Pryntsypy orhanizatsii optymal'noi modeli systemy okhorony zdorov'ia: ukrains'kyj kontekst: monohrafiia [Principles of organization of the optimal model of the health care system: Ukrainian context: monograph], Knyha plius, Kyiv [in Ukrainian].

7. Orlova, N. S. (2019). Mekhanizmy derzhavnoho upravlinnia u reformuvanni systemy okhorony zdorov'ia [Public administration mechanisms in health care reform]. Publichne administruvannia ta natsional'na bezpeka - Public administration and national security, 6. (n.d.). Retrieved from https://doi.org/10.25313/2617-572X-2019-6-5377 [in Ukrainian].

8. Popchenko, T. P. (2012). Reformuvannia sfery okhorony zdorov'ia $v$ Ukraini: orhanizatsijne, normatyvno-pravove ta finansovo-ekonjmichne zabezpechennia: analitychna dopovid' [Reforming the sphere of health care in Ukraine: organizational, normative-legal and financial-economic support: analytical report], NISD, Kyiv [in Ukrainian].

9. Sytash, T.D. (2012). Finansuvannia systemy okhorony zdorov'ia v Ukraini: tendentsii ta reformuvannia [Health care financing in Ukraine: trends and reforms]. Mekhanizm rehuliuvannia ekonomiky - The mechanism of economic regulation, 1, 164-169 [in Ukrainian].

10. The Constitution of Ukraine. (n.d.). zakon2.rada.gov.ua. Retrieved from zakon2.rada.gov.ua/rada/show/254k/96-vr [in Ukrainian].

11. Proekt rozporiadzhennia Kabinetu Ministriv Ukrainy «Pro khvalennia Kontseptsii pobudovy novoi natsional'noi systemy okhorony zdorov'ia Ukrainy: proekt rozporiadzhennia" vid 14 lypnia 2017 roku [projectr of the Cabinet of Ministers of Ukraine "On approval of the Concept of building a new national health care system of Ukraine" from July 14, 2017]. (n.d.). apteka.ua. Retrieved from https://www.apteka.ua/article/295842 [in Ukrainian].

12. Rozporiadzhennia Kabinetu Ministriv Ukrainy "Pro skhvalennia Kontseptsii rozvytku systemy finansovoho zabezpechennia u sferi okhorony zdorov'ia" vid 18 veresnia 2013 roku №776-r [order of the Cabinet of Ministers of Ukraine "On approval of the Concept of development of the financial support system in the field of health care" from September 18, 2013 №776-r]. (n.d.). kmu.gov.ua. Retrieved from https://www.kmu.gov.ua/npas/246773163 [in Ukrainian].

13. Rozporiadzhennia Kabinetu Ministriv Ukrainy "Pro skhvalennia Kontseptsii reformy finansuvannia systemy okhorony zdorov'ia” vid 30 lystopada 2016 roku №1013-r [order of the Cabinet of Ministers of Ukraine "On approval of the Concept of health care financing reform” from November 30, 2016 №1013-r]. (n.d.). zakon.rada.gov.ua. Retrieved from https://zakon.rada.gov.ua/laws/show/1013-2016-\%D1\%80 [in Ukrainian].

14. Zakon Ukrainy "Pro derzhavni finansovi harantii medychnoho obsluhovuvannia naselennia” vid 19 zhovtnia 2017 roku №2168-VIII [Law of Ukraine "On government financial guarantees of medical care” from October 19, 2017 №2168-VIII]. (n.d.). zakon.rada.gov.ua. Retrieved from https://zakon.rada.gov.ua/laws/show/2168-19 [in Ukrainian].

15. Zakon Ukrainy "Pro vnesennia zmin do Biudzhetnoho kodeksu Ukrainy" vid 22 lystopada 2018 roku №2621-VIII [Law of Ukraine "On amendments to the Budget Code of Ukraine” from November 22, 2018 №2621-VIII]. (n.d.). zakon.rada.gov.ua. Retrieved from https://zakon.rada.gov.ua/laws/show/2621-19 [in Ukrainian]. 
16. Zakon Ukrainy "Pro pidvyschennia dostupnosti ta iakosti medychnoho obsluhovuvannia u sil's'kij mistsevosti” vid 14 lystopada 2017 roku № 2206-VIII [Law of Ukraine "On improving the availability and quality of health care in rural areas" from November 14, 2017 №2206-VIII]. (n.d.). zakon.rada.gov.ua. Retrieved from https://zakon.rada.gov.ua/laws/show/2206-19\#Text [in Ukrainian].

17. What has changed in the year since the adoption of the law on medical reform. (n.d.). moz.gov.ua. Retrieved from https://moz.gov.ua/article/reform-plan/scho-zminilosjaza-rik-pislja-prijnjattja-zakonu-pro-medichnu-reformu--[in Ukrainian].

18. Experience of European countries in healthcare financing, lessons for Ukraine. (n.d.). eeas.europa.eu. Retrieved from http://eeas.europa.eu/delegations/ukraine/documents/ virtual_library/14_reviewbook_uk.pdf [in English]. 